\title{
PENGARUH LEVEL PUPUK BOKASHI KOTORAN AYAM TERHADAP PERTUMBUHAN SORGUM BROWN MID RIB (BMR)
}

\author{
Vivi Sandri Bandu, D. A. Kaligis*, Rustandi, W. B. Kaunang \\ Fakultas Peternakan Universitas Sam Ratulangi Manado, 95115
}

\begin{abstract}
ABSTRAK
Sorgum merupakan salah satu tanaman serealia yang potensial untuk dikembangkan di Indonesia karena mempunyai daya adaptasi lingkungan yang cukup luas. Tujuan penelitian ini untuk mengetahui pengaruh level bokashi kotoran ayam terhadap pertumbuhan sorgum brown mid rib (bmr). Penelitian ini, menggunakan rancangan acak lengkap (ral), terdiri dari 4 perlakuan 7 ulangan. Perlakuan sebagai berikut: b1 = $0 \mathrm{~g} /$ polybag, b2 = $200 \mathrm{~g} /$ polybag, b3 $=400 \mathrm{~g} /$ polybag, $\mathrm{b} 4=800$ g/polybag. Variabel yang diukur yaitu tinggi tanaman, jumlah daun dan panjang daun. Hasil penelitian menunjukkan bahwa, perlakuan level bokashi kotoran ayam memberikan pengaruh yang berbeda nyata $(p<0,05)$ terhadap tinggi tanaman, jumlah daun dan panjang daun sorgum bmr. Berdasarkan hasil penelitian ini dapat disimpulkan bahwa, penggunaan pupuk bokashi kotoran ayam dengan level 200 g/polybag, cukup menunjang pertumbuhan tinggi tanaman, jumlah daun, dan panjang daun sorgum brown mid rib (bmr).
\end{abstract}

Kata kunci : Level Bokashi Kotoran Ayam, Sorgum (BMR), Pertumbuhan.

\footnotetext{
*Korespondensi (corresponding aouthor)

Email : kaligis.david@yahoo.co.id
}

\begin{abstract}
EFFECT OF BOKASHI FERTILIZER LEVEL CHICKEN MANURE ON THE GROWHTH OF BROWN MID RIB (BMR) SORGHUM. The purpose of the present research was to determine effect of bokashi fertilizer level chicken manure on the growhth of brown mid rib (bmr) sorghum. The research was used in a completely randomized design arrangement, with 4 treatments and 7 replications. Treatments were formulated as follow : $\mathrm{b} 1=0 \mathrm{~g} /$ polybag, $\mathrm{b} 2=200$ $\mathrm{g} /$ polybag, b3 = $400 \mathrm{~g} /$ polybag, b4 = 800 g/polybag. Parameters measured were : plant height, number of leaves length of leaves. Research result showed that, bokashi fertilizer of chicken manure gave a significant different $(p<0,05)$ on plant height, number of leaves leaves length of brown mid rib sorghum. Based on the research result, it can be concluded that, the utilization of bokashi fertilizer level chicken manure with $200 \mathrm{~g} /$ polybag, enough to support the growth of plant height, number of leaves and leaves length of brown mid rib sorghum.
\end{abstract}

Keywords : Bokashi Fertilizer Level Chicken Manure, Brown Mid Rib Sorghum, Growth. 


\section{PENDAHULUAN}

Di Indonesia terkait dengan masalah pangan pemerintah berupaya mencapai kedaulatan pangan karena berbagai bahan pangan termasuk daging masih tergantung impor. Impor masih dilaksanakan karena dianggap masih lebih murah sebab pengusaha penggemukan sapi dalam negeri memberi konsentrat yang harganya lebih mahal, bersaing dengan kebutuhan pangan dan bahkan energi biofuel, sedangkan di Australia pemeliharaan ternak mengandalkan padang rumput.

Sorgum merupakan salah satu tanaman Serealia yang cukup potensial untuk dikembangkan di Indonesia karena mempunyai daya adaptasi lingkungan yang cukup luas. Teknik budidaya tanaman yang relatif mudah, tidak banyak perbedaan dengan budidaya tanaman jagung yang sudah biasa dilakukan oleh petani. Tanaman ini merupakan salah satu tumbuhan pakan yang tersebar dari dataran rendah sampai dataran tinggi dengan pertumbuhan yang cukup baik dan produksi yang tinggi. Selain itu sorgum tersedia sepanjang tahun dan temasuk salah satu hijauan pakan yang dapat tumbuh pada musim kemarau.

Pemanfaatan sorgum baik sebagai sumber pangan, pakan maupun industri telah banyak dilaporkan. Sebagai bahan pangan, sorgum memiliki kandungan nutrisi yang tinggi, khususnya $11 \%$ proteinnya lebih tinggi daripada beras $6,8 \%$. Sorgum juga mengandung kalium, besi, fosfor, serta vitamin B. Sebagai pakan ternak, biji sorgum digunakan untuk bahan campuran ransum pakan unggas, sedangkan batang dan daun banyak digunakan untuk ternak ruminansia.

Produktivitas sorgum tergantung pada ketersediaan unsur hara dalam tanah yang dapat disuplai dengan pemupukan. Pupuk anorganik dapat memenuhi unsur hara tetapi selain harga mahal jenis pupuk ini berdampak negatif terhadap lingkungan. Tanaman yang kekurangan unsur nitrogen juga dapat menyebabkan daun berkadar serat kasar tinggi, hal ini di karenakan menebalnya membran sel daun sedangkan sel sendiri berukuran kecil-kecil (Sutejo dan Kastasapoetra, 1998). Untuk 
pemecahan masalah tersebut dapat diatasi dengan memanfaatkan kotoran ayam yang dikelolah menjadi pupuk kompos dalam bentuk bokashi. Kotoran ayam yang telah difermentasi dengan EM4 dapat meningkatkan kesuburan tanah, aman terhadap lingkungan dan murah. Penambahan bahan organik dalam tanah akan menyebabkan aktifitas dan populasi mikrobiologi dalam tanah meningkat, terutama yang berkaitan dengan aktifitas dekomposisi dan mineralisasi bahan organik.

Berdasarkan latar belakang di atas telah dilakukan penelitiaan untuk mengetahui dan memperoleh data tentang pengaruh pemberian pupuk organik bokashi yang berasal dari kotoran ayam terhadap pertumbuhan sorgum BMR.

\section{MATERI DAN METODE PENELITIAN}

Penelitian ini dilaksanakan di Laboratorium Agrostologi Fakultas Peternakan UNSRAT Manado, sejak tanggal 23 Febuari - 23 Mei 2017. Bahan yang digunakan dalam penelitian ini yaitu kotoran ayam, dedak halus, EM4, molases, kulit kopi, air, benih sorgum (BMR), dan tanah sebagai media tanam. Alat yaitu; cangkul, ayakan, bambu, parang, gergaji, paku, tali, polybag, meteran, timbangan, kamera, plastik, paku, gunting, spidol, dan alat tulis. Penelitian ini menggunakan Rancangan Acak Lengkap (RAL) menurut Steel dan Torrie (1995). Perlakuan yang diuji adalah 4 level pupuk bokashi sebagai berikut: B1= 0 g/polybag; B2= 200 g/polybag; $\mathrm{B} 3=400 \mathrm{~g} /$ polybag; $\mathrm{B} 4=800$ g/polybag. Perlakuan diulang sebanyak 7 kali, dengan demikian diperoleh 28 angka pengamatan. Data dianalisis menggunakan program minitab versi 16. Apabila terjadi perbedaan rataan dilanjutkan dengan uji Beda Nyata Jujur (BNJ).

Variabel yang diukur ialah jumlah daun, panjang daun dan tinggi tanaman sorgum BMR.

\section{HASIL DAN PEMBAHASAN}

Pengaruh perlakuan level bokashi kotoran ayam terhadap jumlah daun, panjang daun dan tinggi tanaman, dapat dilihat pada Tabel 1.

\section{Jumlah Daun (Helai) \\ Dari tabel 1 terlihat bahwa, rata- rata jumlah daun yang paling tinggi}


Tabel 1. Rataan Pengaruh Perlakuan Level Bokashi Kotoran Ayam Terhadap Jumlah Daun, Panjang Daun, Tinggi Tanaman Sorgum Brown Mid Rib (BMR)

\begin{tabular}{llll}
\hline Perlakuan & \multicolumn{1}{c}{$\begin{array}{c}\text { Jumlah Daun } \\
(\text { Helai })\end{array}$} & \multicolumn{1}{c}{$\begin{array}{c}\text { Panjang Daun } \\
(\mathrm{Cm})\end{array}$} & $\begin{array}{c}\text { Tinggi Tanaman } \\
(\mathrm{Cm})\end{array}$ \\
\hline B1 & $5,21_{\mathrm{c}}$ & $45,02_{\mathrm{b}}$ & $65,64_{\mathrm{b}}$ \\
B2 & $7,00_{\mathrm{b}}$ & $70,68_{\mathrm{a}}$ & $104,73_{\mathrm{a}}$ \\
B3 & $8,14_{\mathrm{a}}$ & $74,06_{\mathrm{a}}$ & $113,12_{\mathrm{a}}$ \\
B4 & $7,93_{\mathrm{ab}}$ & $73,65_{\mathrm{a}}$ & $112,63_{\mathrm{a}}$ \\
\hline
\end{tabular}

Keterangan : Nilai Pada Lajur yang Sama Dengan Superskrip Berbeda Menunjukkan Perbedaan Sangat Nyata $(\mathrm{P}<0,01)$.

terdapat pada perlakuan B3 telah mencukupi kebutuhan tanaman,

8,14 yang diikuti dengan helai, B2 dimana bokashi kotoran ayam memihelai dan yang paling terendah B1 liki kandungan hara makro yang helai. Hasil analisis keragaman me- lengkap terutama nitrogen. Pertumnunjukkan bahwa pengaruh perla- buhan jumlah daun berkaitan dengan kuan bokashi kotoran ayam berbeda peran $\mathrm{N}$ sebagai komponen klorofil, sangat nyata $(\mathrm{P}<0.01)$ terhadap jumlah daun.

Hasil uji lanjut dengan Tuckey Simultaneous Test menunjukkan bahwa perlakuan B3 sebanyak 8,14 helai, B4 7,93 helai dan B2 sebanyak 7,00 helai berbeda tidak nyata $(\mathrm{P}>0.05)$, akan tetapi ketiga perlakuan tersebut berbeda sangat nyata $(\mathrm{P}<0.01)$ dengan perlakuan B1 sebanyak 5,21 helai.

Jumlah daun terbanyak pada perlakuan B3 diduga disebabkan oleh ketersediaan unsur hara yang bertambahnya $\mathrm{N}$ dalam tanah berasosiasi dengan pembentukan dan pertambahan jumlah daun tanaman $(\mathrm{Ku}-$ suma, 2013).

(Rumambi, 2013) Kandungan nutrisi biji sorgum berdasarkan $100 \%$ bahan kering berupa protein (10.26), serat kasar (2.72), lemak (2.70), Ca (0.93) dan P (0.38). Menurut Sucipto, 2010 bahwa kandungan unsur hara $\mathrm{K}$ sekitar 0,40\% yang berpengaruh dalam proses pembentukan daun, dimana tanaman sangat membutuhkan unsur hara Kalium dalam pembentukan karbohidrat se- 
hingga menghasilkan jumlah daun yang banyak. Hasil penelitian ini lebih rendah dengan hasil penelitian dari Hariadi et al., (2015), yang menggunakan kombinasi pupuk kandang dan tricho-kompos memperoleh jumlah daun yaitu 9,83 - 11,69 helai.

Ketersedian unsur hara dalam jumlah yang cukup dan seimbang merupakan faktor utama yang sangat menentukan tingkat keberhasilan pertumbuhan dan perbanyakan jumlah daun tanaman yang maksimum.

\section{Panjang Daun}

Pengaruh level pupuk bokashi kotoran ayam terhadap panjang daun disajikan pada tabel 1 di atas, dari tabel terlihat daun terpanjang pada perlakuan B3 sepanjang 74,06 cm, yang diikuti dengan $\mathrm{B} 473,65 \mathrm{~cm}, \mathrm{~B} 2$ $70,68 \mathrm{~cm}$, dan yang paling terendah B1 45,2 cm.

Hasil analisis keragaman menunjukkan bahwa pengaruh perlakuan bokashi kotoran ayam berbeda sangat nyata $(\mathrm{P}<0.01)$ terhadap panjang daun. Hasil uji lanjut dengan tuckey simultaneous test menunjukkan perlakuan B3 74,06 cm, B4 $73.65 \mathrm{~cm}$ dan b2 $70.68 \mathrm{~cm}$ berbeda tidak nyata ( $p>0.05)$, akan tetapi ketiga perlakuan tersebut berbeda san- gat nyata $(\mathrm{p}<0.01)$ lebih panjang dibandingkan dengan perlakuan b1 $45.02 \mathrm{~cm}$.

Dari hasil yang diperoleh bahwa untuk mendapatkan panjang daun terbaik digunakan pupuk bokashi kotoran ayam maksimal 400 gram/polybag. Didugah bahwa tanaman yang diberikan pupuk bokashi kotoran ayam 400 gram, sudah mencukupi kebutuhan akan unsur hara bagi tanaman sorgum bmr, ditandai dengan grafik yang semakin menurun pada pemberian 800 gram/polybag. Marschner (1995), menyatakan bahwa konsentrasi $\mathrm{p}$ yang tinggi dapat menghambat $\mathrm{Fe}$ dan Zn. Analisis jaringan untuk membuktikan bahwa $\mathrm{p}$ dengan dosis tinggi dapat menghambat penyerapan unsur hara lainnya.terhambatnya unsur hara yang lain akan mengakibatkan produksi tanaman menjadi kurang maksimal.

Hasil yang diperoleh dari pemberian level pupuk 800 gram/polybag pada panjang daun brown midrib sorgum dengan jumlah nilai sebesar $73.65 \mathrm{~cm}$, nyata menurun dibanding perlakuan perlakuan level pupuk 400 gram/polybag $(74,06 \mathrm{~cm})$. Namun berdasarkan hasil uji lanjut dengan 
Tuckey Simultaneous Test menunjukkan perbedaan yang tidak nyata antara B3, B4 dan B2.

Dari hasil yang diperoleh bahwa untuk mendapatkan panjang daun terbaik digunakan pupuk bokashi kotoran ayam maksimal 200 gram/polybag. Diduga bahwa tanaman yang diberikan pupuk bokashi kotoran ayam 200 gram/polybag, sudah mencukupi kebutuhan akan unsur hara bagi tanaman sorgum bmr.

\section{Tinggi Tanaman}

Pengaruh level bokashi kotoran ayam terhadap tinggi tanaman disajikan pada tabel 1. Data menunjukkan rata-rata tinggi tanaman yang paling tinggi terdapat pada perlakuan level pupuk bokashi B3 setinggi 113,12 $\mathrm{cm}$ diikuti dengan B4 setinggi $112.63 \mathrm{~cm}, \mathrm{~B} 2104,73 \mathrm{~cm}$, dan yang paling terendah B1 $65,64 \mathrm{~cm}$. Hasil analisis keragaman menunjukkan bahwa pengaruh perlakuan bokashi kotoran ayam berbeda sangat nyata $(\mathrm{P}<0.01)$ terhadap tinggi tanaman. Hasil uji lanjut dengan Tuckey Simultaneous Test menunjukkan perlakuan B4, B3 dan B2 berbeda tidak nyata $(\mathrm{P}>0.05)$ akan tetapi ketiganya berbeda sangat nyata $(\mathrm{P}<0.01)$ dengan B1. Hasil penelitian ini lebih tinggi dibanding dengan hasil penelitian Pelealu (2002), pada tanaman sorgum yang ditanam di lahan marginal dengan menggunakan pupuk orgazet yang mencapai tinggi tanaman 98,008 cm. Hal ini disebabkan kandungan nitrogen yang tinggi pada pupuk organik asal kotoran ayam dapat merangsang bagi pertumbuhan tanaman terutama tinggi tanaman sorgum Brown Mid Rib.

Nitrogen merupakan salah satu faktor kunci yang membatasi pertumbuhan dan perkembangan tanaman (Fergucon et al., 2010), serta merupakan unsur hara utama juga dalam pembentukan bagian - bagian vegetatif tanaman seperti daun, batang dan akar. Nitrogen juga adalah unsur hara terpenting bagi pertumbuhan rumput secara terus-menerus, karena fungsinya berperan dalam proses fotosintesis (Mc. Ilroy, 2000).

\section{KESIMPULAN}

Berdasarkan hasil penelitian ini dapat ditarik kesimpulan bahwa penggunaan pupuk bokashi kotoran ayam dengan level pupuk 200 g/polybag cukup untuk menunjang pertumbuhan sorgum bmr terukur pada variabel tinggi tanaman, jumlah daun, dan 
panjang daun pada pertumbuhan sorgum Brown Mid Rib.

\section{DAFTAR PUSTAKA}

Fergucon, B. J., A. Indra, S. S. Hayashi, L. Meng-Han, L.YuHsiang , D.E. Reid And P. M. Gressoff_2010. Molecular analysis of legume nodule development and autoregulation. Journal Of Itegrative Plant Biology. 52 (1): $61-76$

Hariadi, F. Puspita, S. Yosewa 2015. Pemberian kombinasi pupuk kandang dengan trichokompas terhadap pertumbuhan tanaman sorgum (Sorghum bicolor.1). Jurnal Agroekoteknologi 2(1) : 4-10

Kusuma, M. E. 2013. Penggunaan dosis pupuk kotoran ternak ayam terhadap pertumbuhan dan produksi brachiaria humidicola pada pemotongan pertama. Jurnal Ilmu Hewan Tropical 4 (1) : 16-20

Marschner, H. 1995. Mineral Nutrition In Higher Plants. Academic Press. New York. $748 \mathrm{P}$

Mc. Ilroy. 2000. Kajian Produksi Dan Pemanfaatan Pupuk Organik.

Http://Banten.Litbang.Depta n.Go.Id//Index.Php/Option. Comcontent\&Viewarticle \&Id $=440 \&$ Itemid=66.19februari2002.

Pelealu, J. J. 2002. Biofertilisasi Micoriza Arbuscular Vasicular. Dalam Pupuk Organic Pada
Varietas Sorgum (Sorghum Bicolor L. Moench) Dilahan Marginal Perkebunan Kelapa. Disertasi Universitas Airlangga. Surabaya.

Rumambi, A. 2013. Karakteristik pertumbuhan sorgum denyang benargan pemupukan urea berbada sebagai sumber nitrogen. Jurnal Agrosistem. $10(1): 1-12$

Steel, R.G.D. And J.H. Torrie. 1995. Prinsip Dan Prosedur Statistic. Diterjemahkan Oleh Bambang Sumantri Edisi Ke-Dua. Pt. Gramedia Pustaka Utama. Jakarta.

Sucipto. 2010. Efisiensi cara pemupukan terhadap pertumbuhan dan hasil beberapa varietas sorgum manis (sorgum bicolor 1.moench). Jurnal Embryo 7 (2) : 67-74.

Sutejo dan kartasapoetra. 1998. Pengaruh Level Nitrogen pada Rumput Gajah (Penisetum Purpureum Schumach). Grass. Journal. Sci, 54 : 146-150. 